\title{
China, Africa and the International Aid System: A Challenge to (the Norms Underpinning) the Neoliberal World Order?
}

Journal of Asian and African Studies

(C) The Author(s) 2021

(c) (i) (s)

Article reuse guidelines: sagepub.com/journals-permissions DOI: $10.1177 / 00219096211063804$ journals.sagepub.com/home/jas

@SAGE

\section{Shaquille Ifedayo Gilpin}

International History, London School of Economics and Political Science, UK

\begin{abstract}
The China-Africa relationship has received increased interest over the past few decades as scholars critically examine the challenge that China, in its quest for a closer strategic partnership with Africa, poses to the norms governing the neoliberal world order (NLWO). One crucial aspect of this is international aid, and how Chinese aid to Africa differs from Western aid. This paper argues that Chinese aid reduces the power of traditional aid donors to shape the development route of African countries. This new development finance ultimately breaks the monopoly of Western aid to decide how poor countries in the global 'South' develop. In doing so, the Sino-African aid relationship is challenging the current world order as it offers African states the possibility to decouple (or delink) themselves from the global economy. By challenging assumed neoliberal economic development fundamentals, this relationship, if harnessed correctly by African leaders, can pose longer-term ideological questions around the very set of ideas that underpin development itself, while enabling African states the policy space needed to pursue more sustainable development from an Afro-centric perspective. It is this possibility to delink, due to changing ideological fundamentals concerning economic development, that is the challenge China and Africa pose to the NLWO.
\end{abstract}

\section{Keywords}

China, Africa, international aid system, monopoly, development finance, development effectiveness, delinking, world systems, neoliberal, decoupling, neoliberal world order

\section{Introduction}

Over the past two decades, the China-Africa relationship has received increased attention within the study of international relations (IR). Scholars are critically examining the challenge that China, in its quest for a closer strategic partnership with Africa, poses not only to the norms underpinning the neoliberal world order (NLWO) but also to the continuity of the order itself. Intrigued by this prospect, this paper argues that the China-Africa relationship is challenging the NLWO through Sino-African aid as Chinese aid to the continent is reducing the power of traditional aid donors to shape the development route of African countries. By offering a new set of ideas and practices,

\section{Corresponding author:}

Shaquille Ifedayo Gilpin, International History, London School of Economics and Political Science, Houghton Street, London WC2A 2AE, UK.

Email: shaquille.gilpin@gmail.com 
China is breaking the monopoly of Western aid to decide how poor countries in the global 'South' develop. It is this alternative supply of development finance that challenges the norms underpinning the international aid system (IAS) and, by association, the NLWO itself. One crucial aspect of this are the constructivist presumptions which underpin international development as they tend to focus on the 'threat' that China's rise poses to the ideological foundations of Western aid. ${ }^{1}$ It is no surprise, then, that while the official narrative from Beijing states that China seeks 'to help developing countries' (Jin, cited in Perlez, 2006) by promoting common development, solidarity and stability based on principles of mutual equality and respect (Xin, 2018), Western scholars are quick to retort, claiming that China is instead a 'rogue creditor' 'underwriting a world that is more corrupt, chaotic and authoritarian' (Naim, 2009). Some even go as far as to call China a 'neo-colonial power' seeking to 'reproduce and deepen existing pathologies within African economies' by further entrenching African dependency within the world systems theory (Amin, 1977; Taylor \& Zajontz, 2020: 277; Wallerstein, 1974). Despite these negative comments, it is possible that China's rising prominence as a global development actor can offer Africa alternative policy options for economic development, while simultaneously posing longer-term ideological questions around the very set of ideas that underpin development itself. From the neoliberal perspective, ideas for development have tended to focus on pro-market economic reforms, political reforms in favour of democratisation, 'good governance', public sector reforms, privatisation, poverty reduction, and either the direct or indirect adoption of other neoliberal initiatives that can, and do, impede the capacity for successful domestic policy formulation and implementation within the recipient nation. By contrast, China's aid to Africa may offer African states increased policy space since Chinese aid, on the surface at least, appears not to be driven by ideological but pragmatic factors. It may also, at least at the theoretical level, offer the potential to gradually decouple (or delink) ${ }^{2}$ Africa from its peripheral position in the current global economic system by enabling African states the opportunity to pursue pro-economic growth and stability policies without the influence of Western nations.

The paper proceeds as follows. First, I provide a brief historical overview of the IAS: I discuss its origins, what it consists of and how it is maintained through global power relations. I then examine the NLWO, what it is and the norms which underpin it. I then seek to show how these constructivist principles, which underpin the NLWO, also underpin the IAS, and how they are central to the functioning of both the aid system and the NLWO itself, using empirical examples. Following this is a critical examination of how China's aid to Africa differs from Western aid at a normative level and the challenge this poses to the NLWO, drawing upon other empirical examples to highlight this difference and the effect it may have on the current world order. Thereafter, is a discussion of whether this alternative aid model is likely to lead not only to an institutional restructuring of the IAS but also the potential for Africa to decouple/delink itself from the global economic system underpinned by neoliberal values. Before concluding, I draw upon the implications and significance of China's influence in international development and what this means for Africa. The concluding remarks bring the discussion and analysis together, offering an overall assessment of China's impact on international aid, and the role that African leaders must now take moving forward.

\section{Brief historical overview of the IAS}

In order to understand today's IAS, we must first familiarise ourselves with its origins as this provides the historical basis for Western neoliberal economic thinking. In its most recent form, ${ }^{3}$ the IAS is a phenomenon of the immediate post-war period, with its origins stemming from the political and economic ambitions of the United States. As the dominant power of the time, the United 
States created a system that preserved and enhanced its own economic and security interests (Williams, 2013). This included the formation of international institutions such as the International Bank for Reconstruction and Development (IBRD, now the World Bank), the International Monetary Fund (IMF), the United Nations Industrial Development Organisation (UNIDO), the United Nations Conference on Trade and Development (UNCTAD) and the US Agency for International Development (USAID). Alongside this were other multilateral frameworks for US-led economic cooperation such as the Marshall Plan. Underlying these initiatives was the belief that the United States should lead the world in the development of a vibrant post-war international economy, particularly because there were few countries at the time that could fulfill the role of foreign lender (Moyo, 2010: 11). Early aid transfers therefore included a US\$250 million reconstruction loan to France in May 1946, and by August 1947, the Netherlands, Denmark and Luxembourg had also received loans to start rebuilding their economies (Moyo, 2010: 11). These aid transfers were instrumental in Europe's economic reconstruction process, enabling it to become the economic powerhouse that it is today (Moyo, 2010: 11).

Given the success of aid in Europe, the United States began to look elsewhere for where they could support in reconstruction and development efforts. So strong was this sentiment that Truman, in his 'Four Point' speech, delivered at his inauguration in 1949, stated that the United States must embark upon a bold new programme 'for making the benefits of our [American] scientific advances and industrial progress available for the improvement and growth of underdeveloped areas' (Truman, 1949). Thus, the aim was twofold: first, to create markets for the United States by improving production in underdeveloped countries (USAID, 2021) and, second, though less overt, was to counter the threat of Soviet communism by supporting the development of third-world countries under the auspices of Western-led capitalism. Characterised by an unfortunate state of absolute poverty, vast unemployment, trade deficits and a lack of infrastructure, the United States turned their attention to Africa. As African countries had limited financial resources, lacked significant domestic savings, and did not have the physical and human capital to attract overseas investment, foreign aid was seen as the only way to spur higher economic growth. As seen in Figure 1 in Appendix 1, ${ }^{4}$ total aid flows to sub-Saharan Africa (SSA) between 1960 and 1990 show an overall upward trend, rising from US\$3 billion to US\$17.5 billion in 2001 prices. Beyond this was the necessity to 'secure transatlantic priorities' in underdeveloped areas to bring peripheral economies closer to Western nations (particularly the United States) and their forms of governance and development (Quirk et al., 2014: 39). In dominating this realm, the United States and its counterparts have been able to shape the norms, scope and rules that govern the IAS.

\section{The IAS and the NLWO as a system of power relations: the theoretical perspective}

In the first instance, the IAS is a part of the global architecture of development finance. It consists of a donor block, or a 'cartel' of good intentions' (Easterly, 2002), that govern the transfer of concessional resources for international development based on donor alignment and harmonisation of certain norms and practices. As a system, it comprises both donor and recipient nations; the donors include the advanced countries of the OECD, while the recipients tend to be peripheral countries in the global 'South'. Since its emergence, this system has developed into a powerful complex of global power relations that shape and frame development at the international level. These power relations are maintained and reproduced due to the large number of donor agencies in the core (with over 150 multilateral agencies and 33 bilateral agencies), private financial flows and non-governmental organisations (NGOs), who control the flow and direction of monetary transfers. Given the concentration of donors in the 
global 'North', these nations can, and do, set the development policies of the periphery due to their vast economic and financial resources, and monopoly on the norms and practices governing international development. This dominant narrative is then appropriated by both donor and recipient states, and later translated into socio-economic development policies led by the global 'North'. However, this development discourse rarely targets key areas, such as agricultural productivity and manufacturing, which would ultimately lead to poverty reduction efforts and increased standards of living. Instead, the IAS encourages African leaders to repeatedly engage with their donors through a dependency relationship which limits their ability to pursue developmental strategies outside of the purview of Western nations (Whitfield, 2009: 9). ${ }^{5}$ This is what ultimately reproduces and maintains their subordinate positions to their donors. John Perkins (2017), a former advisor to the World Bank and IMF, takes this further when he states that African countries are also not permitted to leave the system: 'If the leaders . . . refused to accept loans ... the CIA's jackals would overthrow or assassinate them' (p. 1); it is a system driven by 'fear and debt' (Perkins, 2017: 1). This system, therefore, is not only a hierarchical international regime with its set of norms and principles governing the instruments and modalities of foreign aid but also one which directly threatens the economic foundations of peripheral countries. The Structural Adjustment Policies, the Highly Indebted Poor Countries programme and the Poverty Reduction Strategy Papers are specific examples of this. Needless to say, by enforcing a prescribed set of ideas for socio-economic development on peripheral countries, the IAS prevents many African countries from responding effectively to some of their most challenging developmental issues. An appreciation of this, and the systems which underpin it, are therefore crucial to understanding the nature of power in the IAS and the ways in which this maintains the continuity of the NLWO.

What, then, constitutes the NLWO? To understand this, we must first understand what 'neoliberalism' is. In its theoretical sense, neoliberalism refers to a set of policies that seek 'to realise an ideology of the free market into as many aspects of the political economy as possible' (Harrison, 2019: 275). This is based on the belief that such free market mechanisms are socially optimal, efficient and self-regulating, ultimately tending towards equilibrium. The NLWO then emerges when these neoliberal concepts are enforced by free market enthusiasts in the policies of other countries who do not necessarily have the domestic environment to follow these principles, nor implement them effectively. In the post-war era, Western nations, particularly the United States, have exported these neoliberal ideas in what can be referred to as the 'expansion of neoliberal hegemonic globalisation', where many nations worldwide, especially those in Africa, were forced to implement them. This division of the world into 'policy makers' and 'policy takers' forms a crucial part of the world systems theory, and the nature of the global economy, as it has created a 'rather specific pattern of asymmetric interdependence' whereby the dynamic process which linked the global 'North' to the global 'South' in the global economy was 'permeated by the neoliberal economic ideology, presented as a policy package for developing and underdeveloped countries' (Vadell et al., 2014: 95). The NLWO is then the result of these asymmetric power relations at the global level defined, mediated, maintained and reproduced by Western aid organisations and economic thinking.

Important to recognise is that the world systems is split into primarily core and peripheral nations (Wallerstein, 1974). ${ }^{6}$ The dominant states (the core, primarily Western nations) are those which prescribe neoliberal policies, while the dependent nations (the periphery) are usually African. Given that peripheral nations are 'policy takers', they are often dependent on the (neoliberal) policies of the core, thus making African countries dependent on external forces given the nature of their integration as peripheral nations in the world systems (Ocampo, 2001). I argue that these external forces, for the purposes of this paper, are primarily the Western aid organisations. 
Important to note, however, is how contemporary underdevelopment has evolved from the imperialist era, to the colonial era, to present day. Gunder (1986) argues that

contemporary underdevelopment is in large part the historical product of past and continuing economic relations between the satellite underdeveloped and the now developed metropolitan countries [which] are an essential part of the capitalist system on a world scale as a whole. (p. 113; emphasis added)

In other words, the interplay, between the core and periphery in the global economic system, is a dynamic process that is constantly evolving. Today's global capitalist system requires the repeated and prolonged interaction of the core with the periphery through the world systems to maintain the current international economic system, or the NLWO. One of the mechanisms used to maintain the NLWO is, therefore, the IAS. Despite appeals from Western scholars that international aid, based on neoliberal ideals, is designed to curtail poverty, improve development efforts and build infrastructure, I argue that aid is simply a means for Western nations to continuously serve their own economic, political, and strategic interests at the expense of the recipient nation. International aid, guided by neoliberal principles, simply enables Western nations the liberty to maintain their influence and control over the pace and direction of Africa's socio-economic development.

\section{The symbiotic relationship between the IAS and the NLWO: the empirical evidence}

To demonstrate how this global theory operates at the national level in the recipient countries, and how the IAS and the NLWO work together in practice to maintain the current global economic system, it is important to analyse the empirical data. One way to do this is through analysing the impact of structural conditionality on African countries using the example of cotton and Mali in the 1990s. During the 1990s, the World Bank and IMF advocated for the privatisation of Mali's cotton sector and argued for the liberalisation of the pricing system, which made the price of cotton dependent on world markets (Molina \& Pereira, 2008: 16). The cotton industry, if properly protected, could have played a crucial role in the economic development of many West African countries, given its importance for the textile industry (Hussein et al., 2005: 9), while also providing farmers with subsistence and income. It is also produced using little input and cheap labour which gives Mali (and other cotton producing nations) a comparative advantage in cotton production. Cotton production, therefore, not only has the potential to improve incomes, livelihoods and the overall economy of a country, but can also provide economic sustainability by developing its quality to sell to international markets. And, similar to how cotton was one of the main raw materials for the Industrial Revolution, cotton could also have the same transformative impact on cotton-producing countries, thereby potentially enabling these countries to gradually delink themselves from their peripheral positions in the global economy and become more economically independent. However, by pushing for privatisation and liberalisation of the Malian cotton industry, the IMF heavily distorted cotton prices due to international market volatility, ultimately lowering domestic prices and incomes for Mali and its cotton producers (Hussein et al., 2005: 9). The argument for this neoliberal reform was that it would 'improve management and increase cotton prices while decreasing the cost of farm inputs' (Molina \& Pereira, 2008: 16). However, data from the World Bank and Oxfam International show that the immediate impacts were a collapse of households' purchasing power, increased poverty and food insecurity, and rising debts (Molina \& Pereira, 2008: 16; Oxfam International, 2006: 20; World Bank, 2005). 
Furthermore, prior to the 1970s, Zambia was also considered one of the more wealthy African countries. Traditionally, the landlocked country had used copper mining as a way to gain foreign exchange earnings. By the mid-1960s, Zambia was considered a major player in the global copper market as it accounted for approximately $12 \%$ of global production, and by 1969 had been classified as a middle-income country with its gross domestic product (GDP) higher than that of Ghana, Kenya and even South Korea (Sikamo et al., 2016: 2412). What is more, the mining sector provided direct and indirect job opportunities that by 1972 approximately 62,000 people were earning their incomes from the national mining industry (Sikamo et al., 2016: 2412). This led to economic independence and sustainability, enabling the growth of other sectors also, such as trading, construction, transports and manufacturing (Sikamo et al., 2016: 2412). However, after the oil crisis of 1973, which increased the price of imports and reduced the relative price of mining, the IMF and World Bank offered loans to Zambia (Situmbeko \& Zulu, 2004: 7). By the early 1970s, Zambia's total external debt rose from US\$814 million to US\$3244 million. By the end of the 1980 s, the external debt owed to the World Bank and IMF equalled US\$6916 million (Situmbeko \& Zulu, 2004: 7). Such high levels of debt essentially cripple an economy, enabling the donor to wield increasing influence over the recipient nation. In return for debt relief, Zambia had to adopt neoliberal policies such as privatisation, public sector reforms, deregulation and so on. What occurred was a reduction in real GDP per capita from US\$1455 in 1976 to US\$892 by 2000 (Situmbeko \& Zulu, 2004: 9). Some may argue that debt relief is a 'veritable launch-pad to Africa's development', but the truth is that the neoliberal conditions which prevailed prior to the debt crisis still persist in the debt relief regime (Omotola \& Saliu, 2009: 87). ${ }^{7}$ This debt crisis, therefore, further entrenched Zambia in its peripheral position in the world systems, thereby maintaining the NLWO.

Similarities can be drawn to other countries like Zimbabwe. Research conducted by Kabonga (2017) in the Chegutu district found that Western aid prevented economic sustainability. He argues that there are some donor aid projects, such as the feeding scheme, which 'epitomises dependency' (Kabonga, 2017: 7). He further claims that many African countries 'have their budgets dependent of Official Development Assistance' making it 'clear that donor aid in multifarious ways is the quintessence of dependency' (Kabonga, 2017: 8). However, this is not to say that all Western aid given to Africa is 'bad'. In countries like Botswana, for instance, it is argued that good institutional frameworks have enabled the country to thrive from donor aid. The book, Uganda - The Dynamics of Neoliberal Transformation, also provides some evidence, based on research from both Ugandan and international scholars (Wiegratz et al., 2018) on how neoliberal economic policies, despite being heavily criticised, have provided some benefit to this African country. ${ }^{8}$ Christine Lagarde even defined Uganda as 'an African success story' (Biryabarema, 2017; Lagarde, 2017). Some econometric data further claims that foreign aid has a 'positive and strong' effect on some West African countries (Adamu, 2013), as well as having a 'statistically significant' effect in reducing poverty in Africa (Mahembe and Odhiambo, 2021). Conversely, econometric data from other scholars finds that 'for African countries, foreign aid has . . minimal effect on economic growth' (Alghamdi, 2016: iii). Indeed, while it may be true that, in some cases, improved institutional frameworks could enable certain African countries to make better use of Western aid by providing a more stable environment for improved economic growth, is it necessarily the case that they may be able to remove themselves from their peripheral positions in the current world systems through the same aid providers who created the NLWO in the first place? I argue that the nature of the world capitalist system makes it almost impossible for Africa to leave it and pursue policies that favour its environment that lead to genuine socio-economic development simply because the 'North'-'South' relationship requires the continent to stay in this peripheral position. 


\section{China's aid to Africa: the normative difference to traditional donor aid}

China's aid to Africa, then, provides a challenge to the NLWO as it offers a new way of thinking about international aid and development that diverges away from Western aid. At a normative level, there are key characteristics which separate Chinese aid from Western aid. First, development effectiveness, that is to say, a 'development-first' approach. The reason for this is that it was only when China pursued development effectiveness that it was able to overcome its development challenges and emerge as a world player (Pan, 2015: 289). Official Chinese documents also state that 'practice has proved that a country's development depends mainly on its own strength' (China International Development Cooperation Agency (CIDCA) 2011). In other words, international aid must seek to economically develop a country so that, that country can then be able to continue economically developing itself. For this reason, Chinese aid to Africa targets specific areas for economic growth such as infrastructure, education, healthcare and public facilities (Pan, 2015: 287). The aim, it is argued, is to improve the selfdevelopment capabilities of African nations, helping them to better their national industries. This will help to create more jobs, thereby generating increased income for the local people and improving their standards of living (Pan, 2015: 288). In essence, Chinese aid seeks to 'transform societies in order to achieve positive and sustainable development outcomes for its citizens' (Stern, 2008: 19). Traditional donors, by contrast, tend to promote aid effectiveness over development effectiveness. They focus on how aid is planned, managed and deployed, programming it in ways that advocate for conditionality, selectivity, good governance and anti-corruption (Woods, 2008). Chinese aid to Africa, therefore, departs from the norms underlying the IAS by seeking to achieve development-first. In doing so, it provides an alternative source of development finance crucial to economic growth, thereby ultimately gradually reshaping how aid is conceived or understood in the existing aid system.

Second, China employs a state-led developmental model in its aid which directly contrasts to Western ideology. Within mainstream Western thought, scholars have tended to support the neoliberal free market approach, de-emphasising the role of the state and letting the 'invisible hand' direct the economy (Rafferty, 2011: 32). This development discourse later underpinned the structural adjustment policies imposed on African countries in the 1980s and 1990s. China, however, highly values government-led investment, particularly in infrastructure and agricultural productivity, which helped facilitate its own economic growth. In doing so, it bases its economic success 'on the capacity of state institutions to shape an assertive industrial policy around locally derived priorities' (Rafferty, 2011: 33), which essentially calls into the question the effectiveness of the Western free-market development model for African countries. Most obviously, then, China's donor policies reflect this state-led approach which shows African states that there are alternative and credible means for development outside of Western neoliberal capitalism.

Finally, China is contributing to the changing the norms of the IAS through its 'reform on conditionality' (Rafferty, 2011: 34), insisting on non-interference in domestic affairs and a 'no-strings attached' approach. In choosing not to impose political conditions, China is enabling recipient countries to independently choose their own development path, unlike traditional donors (Pan, 2015: 295-296). China is also giving African states the policy space needed to make decisions on their own. In doing so, it is showing that aid does not need conditionality to be effective, which could potentially give African countries greater economic and political influence in domestic and international development negotiations. This is not to suggest, however, that the ideological fundamentals of donor nations will disappear entirely. The point is instead to show that the monopoly traditional donors have on aid is not the same as it was forty years ago. China's entry into the 
system, and its relationship with Africa, is challenging traditional donor beliefs on the international stage, and this is the power behind the China-Africa relationship in the IAS.

\section{Projects, infrastructure and socio-economic development: a potential African decoupling/delinking from the global economic system?}

\section{Criticisms}

In order to explain how China's aid to Africa may offer a potential African decoupling (or delinking) from the world capitalist economy, it may be best to begin with the criticisms against Chinese aid. One of the more prominent claims is that China is (re)creating a new type of African dependency through schemes such as the Belt and Road Initiative (BRI) and 'debt-trap diplomacy'. Debttrap diplomacy is a term used to refer to a creditor country that loans a large amount of money to the debtor country with the intention of gaining some sort of economic or political leverage over the recipient nation when the borrowing nation eventually defaults on repayment by the maturity date. ${ }^{9}$ In the case of Ethiopia, one study sought to 'unmask' China's win-win cooperation strategy by demonstrating China's 'land-grabbing motives'. The study found that China 'oversells the benefits of infrastructure projects ... and offers credit to commence the projects on onerous terms via its own EXIM Bank' (Addis et al., 2020: 21). In Ethiopia, they argue that the loan conditions are opaque and are often conducted without the knowledge of the public. Thus, it is much easier to build up a foreign debt given that Chinese loans are seen to be 'much easier, cheaper . . . quicker ... and with fewer strings attached' (Addis et al., 2020: 21). Furthermore, they claim that loans for projects such as the Addis Ababa double-track light railway (the loan for this was US\$475 million from the EXIM Bank) and the Ethio-Djibouti electric standard-gauge international railway, of which $70 \%$ is financed through the EXIM Bank, is barely making any profit (Addis et al., 2020: 22). The Ethio-Djibouti railway is also stated to have 'stopped its operation before beginning the repayment of its loan' (Addis et al., 2020: 22). As a result, Ethiopia is left without a functioning railway system and a burgeoning debt burden. In a way, this may be reminiscent of a similar dependency relationship that exists between the 'North' and the 'South'.

Tarrósy (2020) elucidates similar issues when he discusses the BRI. He describes it as an 'ambitious vision of China to increase its connectivity with the African continent, across which it has assertively managed gradually deeper engagements' (Tarrósy, 2020: 10). He further states that it is a 'composite geopolitical tool for enhancing China's positions globally' (Tarrósy, 2020: 11). In September 2018, President Xi Jinping claimed that US\$60 billion would be offered to Africa to improve financing through interest-free and concessional loans (Tarrósy, 2020: 10-11). Thus, the issue that Tarrósy finds is that these infrastructure development projects, which are arguably at the heart of the BRI, may 'reproduce dependency' from China (Tarrósy, 2020: 10-11). He continues, 'The Chinese government explicitly urged both state-owned enterprises and private firms to penetrate local markets across the globe, taking advantage of a dynamic new phase of world trade and hunger of developing regions for investments in infrastructure' with the aim of 'improv[ing] and strengthen[ing] [China's] geopolitical position' (Tarrósy, 2020: 10-11). Under such circumstances, it could be believed that China may employ debt-trap diplomacy techniques, such as opaque loan agreements that, that Africans may not be aware of (Tarrósy, 2020: 10-11). This is also in line with the rhetoric from the former Treasury undersecretary for international affairs, Timothy Adams, who told the Wall Street Journal that, "there are some aggressive countries out there that are ramping up their export-credit agencies and looking to take advantage of countries with lightened balance sheets' (Phillips, 2006). Hillary Clinton and Mike Pompeo have echoed this sentiment, 
making similar comments on China's 'predatory economics 101' (Voice of America, 2018) and 'hawk' behaviour (Financial Times, 2016). Thus, it could be that China is using the BRI and economic loans to reproduce a similar dependency relationship with Africa in its quest for global leadership through debt-trap diplomacy.

\section{Exaggerated claims?}

However, how true are these claims? According to Chinese source, Xinhua (2021a), 'there is no evidence to support [the] narrative of China's engagement in debt-trap diplomacy'. It further claims that there is also "no evidence China aims to deliberately push poor countries into debt as a way of seizing their assets or gaining a greater say in their internal affairs' (Xinhua, 2021a). Furthermore, empirical data from China's lending activity do not support such claims. In fact, numerous scholars note that such claims only exist because of rumours, unreliable reports, and a lack of investigative rigour (Brautigam and Hwang, 2016; Gallagher, 2016; Singh, 2020). The China-Africa Research Initiative (CARI), ${ }^{10}$ which produces highly accurate and reliable estimates of Chinese aid to Africa, has also affirmed that 'Chinese lending is relatively small, with less than 15\% of debt stock' (CARI, 2020: 12). In other words, a lot of Africa's 'debt problems are largely caused by lenders other than China' (CARI, 2020: 12). The Jubilee Debt Campaign (2018), a debt relief coalition, also conducted a country-by-country quantitative analysis of African government external debt and further 'concluded that China is not the major driver of debt distress on the continent'. Instead, over $65 \%$ of African external debt is to traditional donors such as the World Bank, the IMF and non-Chinese private creditors. In addition, data from the IMF and World Bank have also identified 16 African countries to be in debt distress or at high risk of debt distress (Singh, 2020: 244-245). Of these 16 countries, 'the mean average amount owed to China was found to be $15 \%$, with only three governments found to owe more than a quarter of their external debt to China' (Singh, 2020: 244-245). In Ethiopia, however, the evidence from CARI does indeed state that China is 'the single most significant creditor, with outstanding debt of US\$ 8.7 billion', which is 32\% of Ethiopia's public debt (CARI, 2020: 12). The World Bank is in second place, with 31\%. With that said, however, the criticisms against Chinese aid to Africa may be exaggerated.

The case of Mali provides a strong example. Recall that under neoliberal economic policies, Mali's cotton industry lost its competitiveness. However, Mali's diplomatic relationship with China has enabled the country to develop through Chinese investment. For example, in 2014 China invested US\$8 million in Mali to construct over 500 miles of railway track. This track would propose to connect Mali with neighbouring countries, such as Guinea Conakry (Zan, 2015: 28). In 2015, China also committed to reconstructing the 1286-km metre-gauge line that connected Bamako to Dakar (Reuters, 2015). What this shows is China's development-first approach to aid as it was the poor economic infrastructure and the lack of funds for construction that inhibited Malian development. As opposed to the neoliberal policies, China has directly sought to improve the economic environment in Mali. Such instances show that, even in poor African countries, if development-first approaches are adopted, and investment is made in construction and infrastructure, such countries can develop. And, to some extent, it is the Mali-China aid relationship that has strengthened Mali's economy. This improved transport network may also attract foreign investors to resources such as iron ore, bauxite and uranium.

In the case of Zambia, a similar story can be seen. According to Chinese news sources, in July 2021, China offered US\$2 billion to finance the launch of the Kafue Gorge Lower Hydropower Station in the southern district on Chikankata (Xinhua, 2021b). It is argued that, on completion, this project 'will add 750 megawatts of electricity to the country's power grid reducing frequent 
power shortages' (Xinhua, 2021b). Without such financing, Zambian infrastructure is unlikely to be built. In countries such as Kenya, Nigeria and Tanzania, China has also carried out several projects, some of which include 14 small hydropower projects. Of particular interest is also the 'lighting up Rural Africa' project, which seeks to provide electricity in rural communities in Africa (Agbebi \& Virtanen, 2017: 443). Agriculture, technical exchanges and cooperation therefore seem to form the backbone of Sino-African projects. For instance, at the end of 2014, China's Ministry of Commerce (MOFCOM) approved a total of 377 manufacturing projects in Nigeria (128), Ethiopia (80), South Africa (77), Tanzania (48) and Ghana (44) (Agbebi, 2017: 442). Infrastructurefinancing projects are also present in over 35 African countries, with Nigeria, Angola, Sudan and Ethiopia being some of the largest recipients (Agbebi \& Virtanen, 2017: 442). While the nature of these projects can be critiqued by Western scholars, what cannot be denied is the contribution to industrial capacity China is having in Africa. These projects could potentially improve gains in human capital development by offering increasing opportunities for employment and skills development, while also improving technology transfer for the indigenous people. This is important because China is enabling Africa the opportunity to engage in, and improve, its productive capacity. Indeed, it is still true that China maintains the industrial advantage and, unsurprisingly, has more power. However, in contrast to the 'North'-'South' relationship, which has relegated Africa to the sole position of primary commodity exporter, China's projects in Africa offer the continent the opportunity to upgrade its economic output through gradual industrial development.

\section{Indigenous people}

Related to indigenous people, however, one criticism often raised in the literature against China is that it employs its own labourers to work on the projects it funds in Africa. Critics use this to argue that China is neocolonialist and seeks to control Africa. One reason for this, however, may stem from the unfortunate 'low levels of capacity in many African countries' (Brautigam, 2011: 157). This does not necessarily imply that a neocolonial relationship is at play. Rather, this could be an opportunity for training, up-skilling and culture-sharing between China and the many African countries. For instance, as opposed to only showing the developed aspects of China, Chinese officials and academics are also willing to show Africans China's less-developed regions so that the Sino-African relationship can be seen as a more 'South'-'South' relationship, and truly emphasise the fact that China sees itself on an 'equal footing' with Africa (Sun et al., 2021: 863). China also presents itself as a 'peaceful culture sharer rather than 'a value imposer' exemplified by the US' (Sun et al., 2021: 864). For example, between 2006 and 2009, China pledged to offer university scholarship programmes for 4000 Africans to earn degrees in China that will not only lead to improved mutual and cultural understanding between China and Africa but also potentially lead to higher levels of sustainable development (Brautigam, 2011: 158). In 2015, a report published by the Chinese Academy of International Trade and Economic Cooperation also stated 'that $82 \%$, or 17,600 employees, of the Chinese National Petroleum Corporation staff in Africa are local hires', while the 'Chinese National Minerals Corporation has hired 12,500 workers in Zambia' (Benjelloun, 2015: 5-6). In 2019, further research conducted by the School of Oriental and African Studies (SOAS) on 76 companies and 1500 workers in Angola and Ethiopia (since the two countries are top destinations for Chinese foreign direct investment) found that the negative stories levied against Chinese companies were popular misconceptions. In Ethiopia, the research stated that 'about $90 \%$ of workers [at Chinese companies] are, in fact, Ethiopians' (Schaefer and Oya, 2019), while over the past 10 years, Chinese businesses have been employing more Angolan workers, increasing localisation rates 'from around $50 \%$ in the early days of post-conflict reconstruction to the current rate close to 75\%' (Oya and Wanda, 2019). Indeed, while further research will be required to 
evaluate the nature of their work, the positions many Africans hold in these companies and how much influence they have in decision-making processes, the available research suggests that far from depriving Africans of work, China is increasingly engaging local Africans and contributing to employment creation efforts.

\section{Industrialisation efforts}

More examples of how Chinese aid contributes to industrialisation in Africa include the Huajian group which established a shoe manufacturing factory in Ethiopia in 2011 (Agbebi \& Virtanen, 2017: 443). After only 3 years, the shoe factory had improved local employment prospects by creating 4000 jobs. Not only this, they also began manufacturing shoes in Ethiopia for export to the global market (Lin, 2016: 11); thus, a value-added product that could improve the Ethiopian economy. In Rwanda, we see another similar example: Chinese investors established a garment manufacturing factory, C\&H garments, in 2015, and have thus far employed 500 local workers, trained them and is currently exporting from Rwanda to foreign markets (Lin, 2016: 12). It must be admitted, however, that for many African states, the ideal situation would be to not have foreigners within their countries stimulating their economies and controlling their businesses at all. However, given the lack of domestic funds and infrastructural development, and whatever the true motivations are behind China's aid to Africa, what cannot be overlooked is how China is increasing Africa's production and trade capacity not only within the continent but also globally.

If possible, African countries can begin to harness this increased development and employment creation to then facilitate their own continued industrialisation. Through effective decision-making policies, the opportunity to leverage China's investments for these countries' socio-economic development is possible if used through 'concrete industrial and localisation policies and strategies followed through with effective implementation' (Agbebi \& Virtanen, 2017: 443). Other African countries can use the examples of Rwanda and Ethiopia to exert increased agency in how they use Chinese investments. It is perhaps even more interesting to recognise that within FOCAC (Forum on China-Africa Cooperation), China focuses on cooperation to foster industrial development in Africa. Even President Xi Jinping stated that a new 'China-Africa Industrialisation Program' has been created to enhance Africa's industrial capacity, which clearly reflects China's support for Africa's industrialisation (Ministry of Foreign Affairs of the People's Republic of China, 2015). There was also a US $\$ 10$ billion pledge to create a new China-Africa industrial cooperation fund (Xinhua, 2018). This will include industrial parks, regional vocation education centres and capacity building schools. The fund also promises to train 200,000 technical personnel and provide training opportunities for 40,000 African personnel in China. Indeed, such promises are yet to materialise, and it will require agency from both Chinese and African officials, but especially African officials, before the results emerge. Despite this, Chinese investments in Africa continue to demonstrate increased opportunity for employment, training, skill building, technology transfer and human capital development.

Chinese investments in Africa are not entirely altruistic, however. As a nation, China requires natural resources and conducts its business in ways that are favourable to itself. It primarily imports natural resources from Africa, while it exports manufactured products. This fact can lead to the unfavourable view that China is, again, neocolonialist, and that the African continent has once again found itself in unbalanced power relations that are reminiscent of its relationship with the global 'North'. However, from an African perspective, the opportunity to have more international trade partners gives these countries greater leverage in international trade, as well as the possibility for increased economic growth. Through the spirit of 'win-win' relations and equal partnership, China may be gradually divulging Africa from its peripheral position in the world systems. 
Furthermore, an economist at the University of Tokyo, Jean-Claude Maswana, has conducted numerous investigations into Sino-African relations and compared it with the world systems concept. In 2007, what he found was that, 'for the first time Africa is drastically shifting its trade pattern away from its colonial framework' (Maswana, 2007: 1). In 2018, he revisited the growth effects of Sino-African trade on African economies and his findings suggested a 'heterogeneous trade-growth nexus with the effect of bilateral trade intensity on Africa's economic growth being higher in countries whose trade intensity with China is higher' (Maswana, 2018: 1). In other words, China's economic growth and investment in Africa coincides with improved African trade. African countries should seek to capitalise on this investment as it may offer them the opportunity to delink from the world capitalist economy through trading in manufactured goods.

\section{A potential delinking?}

One reason for this is that, in contrast to the NLWO, China does not appear to force African nations to adopt policies they do not want. On the contrary, the policies seek to industrialise these countries. A delinking from the global economic system may then only emerge once there is a reduction in unequal exchange, that is, once African states become more economically independent. The primary reason for this stems from the 'polarisation' law as 'the inherent law of the capitalist world-wide expansion' (Zhang, 2013: 103). To delink, African countries first need to adopt new economic strategies and values that differ from the global 'North', which China offers. African countries must then control their own labour force, agricultural development and food self-sufficiency. This will allow African states to gradually achieve 'auto-centric development', perhaps in a similar way to countries like China, Korea and Taiwan. While there were criticisms about poor Chinese labour practices, however, research from Chen et al. (2016) actually shows that Chinese firms in Nigeria, for instance, employ $80 \%$ of their workforce locally, and engage in workforce training (p. 12). Thus, this could be a step towards allowing Africans to control their own African labour force. Third, the improvement of capital controls (which comes from regulation not deregulation) can allow domestic ownership over state-directed investment. This will require astute African leadership in their dealings with the Chinese to ensure that Africans win while the Chinese also win. Domestic production, with access to natural resources, controlled by Africans, will also enable African countries to produce, become independent, and perhaps even competitive. Thus, the nature of African exports will no longer need to be focused on natural resources but instead valueadded products. To make the jump from natural resource exports to manufactured goods will undoubtedly require Chinese assistance. African states should then continue to emphasise diplomatic, military, economic and cultural relations with China, utilising Chinese efforts as much as China uses African efforts.

Improved technologies for better industrial development, which could be achieved through technology transfer and, finally, state-led control over the policies implemented for economic growth are other important factors for delinking (Pérez, 2021: 105). China has provided a useful blueprint for African countries which they can use as inspiration. Given Chinese investment and support, it is not far-fetched to say that an African delinking from the NLWO is possible in the future. This is not to say that a complete decoupling from the global economy will occur, however, whereby Africa completely severs its ties with the rest of the world. One reason for this is the interdependent nature of today's economic globalisation. Many African states will have to go through the processes outlined above before delinking occurs. China's investment and opportunities for local up-skilling, increased domestic labour productivity and overall infrastructural development, provide a possible launchpad for Africa. It will be down to brave and ethical African leaders to best harness the Sino-African relationship for their people and their countries, thereby leading the way 
for the decoupling/delinking process to occur. Some scholars may still choose to defend neoliberal aid policies, citing World Bank technical assistance to some African central banks and the building of institutions. However, the truth is such examples are more the exception than the rule.

\section{An institutional restructuring of the IAS and the creation of an alternative aid system?}

With this in mind, the question then becomes: is there likely to be an institutional restructuring of the IAS and/or the creation of an alternative one? Will China likely be the leader of this initiative? And will neoliberalism cede to a Sino-centric 'world order'? On one hand, some argue that China's developmental presence in Africa, especially in infrastructure and investment, demonstrates that it is now a visible actor in the system (Opoku-Mensah, 2010). They point to the increased volume and size of Sino-African aid over the past two decades ${ }^{11}$ as proof of this, claiming that is better adapted to Africa 'than the slow and sometimes patronising post-colonial approach of [Western] donor organisations' (Wade, 2008). What differentiates Chinese aid, therefore, is its modality; that is, the way it is delivered and the amount of ownership that recipient nations have in the Sino-African aid relationship (Ohno \& Niiya, 2004: 26). Aid that reflects local goals and priorities, and is genuinely based on a consultative national consensus, as opposed to donor policy conditionality, is what enables developing countries to formulate a development strategy and stimulate economic growth. This, as stated, challenges the norms and ideas which underpin traditional donor aid as it leads to tangible developmental results and increased agential power on behalf of the Africans.

On the other hand, it would be short-sighted to claim that traditional donors no longer have power in the IAS. Western multilateral organisation, such as the World Bank, the UN and NGOS, alongside the major donor nations, still dominate the implementation of the most influential ideas and strategies of development (Opoku-Mensah, 2010: 81). Politically, their systems and structures continue to influence the ideas which underpin development, constantly updating and refining knowledge about how best to achieve development (Opoku-Mensah, 2010: 81). In many ways, this conceptual power, which enables the West to define what is considered good or bad development, and to impose these definitions on African countries, is still how the IAS operates. Ikenberry (2018) takes this a step further when he states that 'non-Western states also have an interest in the preservation - and perhaps the expansion - of a rules-based international system' (p. 26). He argues that what China wants is the 'West's rules and organizational principles [without] Western dominance of global institutions' (Ikenberry, 2018: 25). In other words, China seeks not to restructure the IAS, nor challenge the norms which underpin the NLWO, but would instead prefer to have greater influence, authorship, and leadership within this system.

On one hand, it is difficult to argue against the continuity of the NLWO, especially that which is maintained and upheld through Western aid, as this order is based on deep rules and norms adhered to by many countries. Similarly, the economic gains donor nations make through aid may incentivise other nations to join the Western donor bloc and its multilateral institutions. Once nations like China join, the argument goes that they will then be incentivised to maintain these systems and norms. On the other hand, however, despite being a beneficiary of neoliberal economic policies, which facilitated China's meteoric economic rise, can it really be argued that China has an 'interest in the preservation' of the NLWO? Instead, could it not simply be that it is currently in China's benefit to partake in the system? Dams and van der Putten (2015) exemplify this point:

To argue that China integrates into the international order for the sake of liberalism would be to reason the wrong way around: China will be compatible with norms based on liberalism as long as such norms are 
compatible with Chinese interests. China is not integrating into the liberal international order because it shares the liberal ideology, but because it serves China's needs. (p. 13)

China's aid to Africa, therefore, is simply introducing a new understanding of development by enabling African countries the opportunity to pursue alternative development policies as a way to be truly independent and protect their political choices. Aforementioned factors, such as state-led development and development effectiveness, are the normative challenges that China is posing. The 'Beijing Consensus', if we can call it that, is therefore a 'legitimate challenger to the Western status-quo providing an alternative to the unhealthy economic dependency which has grown between Africa and its former colonial masters' (Sempiga, 2017: 11). Given China's historical evolution, and cultural values, it may even be that Chinese aid is a more suitable choice for Africa as long as African leaders themselves exercise increased agency and influence over their terms of development.

Despite this, research suggests that China is not looking to directly challenge the rules and principles of the NLWO and the IAS, at least not in the way that Soviet Communism did in the Cold War. Instead, China's influence may be more subtle; constrained by the conceptions of US predominance, China may choose to only promote new ideas, while also openly supporting SouthSouth cooperation (Rafferty, 2011: 40), thus accepting the NLWO and not posing an alternative grand narrative of a new world order. It appears, instead, that China is using its relationship with Africa to set a new tone to IR, and this is the ideological/normative challenge it poses. In the future, factors such as state-led development, development-first approaches and equality could be the drivers for better cooperation among states, as opposed to the often used condescending and neoliberal tones of traditional donors.

It is unlikely, however, that traditional donors will allow China to price them out of the market in Africa. Schemes such as the China-DAC (Development Assistance Committee) Study Group, established in 2009, could be developed and expanded to incorporate Sino-African ideas on development based on mutual learning and understanding. While the Study Group currently only incorporates China and OECD countries, it may be worth expanding this to include Africans. As China recognises, what works for China may not necessarily work for Africa, but an open dialogue where all parties contribute to the advancement of global development may set the path for a more equal world where the core-periphery dynamic is no longer as pronounced. Needless to say, what I believe China's role in the IAS seeks to demonstrate is that the prevailing ideas on development, which African states were forced to follow, are no longer the only option. With the support of China, African countries can be freer to pursue alternative development policies which are more in line with their economic conditions. By proposing new ideas on how aid is conducted, China is breaking the monopoly of traditional donors to conceptually define development. Because of this, as this paper has sought to demonstrate, the China-Africa relationship is therefore challenging the norms underpinning the NLWO through international aid since it is reducing the power of traditional aid donors to shape the development route itself. In doing so, it may provide African states the opportunity to gradually delink themselves from the global economic system.

\section{Concluding remarks}

China, like any other sovereign nation, has its own beliefs and ideas on development, and how it should be conducted. I believe that there is no better example of this than that which concerns its relationship with Africa. If traditional donors fail to respect this, they may risk alienating China from the international community. Second, the China-Africa relationship is a strong example of South-South cooperation. ${ }^{12}$ As defined by the UN (2020), this 'is a manifestation of solidarity 
among peoples and countries of the South that contributes to their national well-being, their national and collective self-reliance and the attainment of internationally agreed development goals'. If the IAS fails to demonstrate it can accommodate the needs and desires of the developing world, it could be that China seeks to establish its own regime that better reflects its own development perspectives. Given its vast economic network, created through its development finance, the empirical evidence of its support in Africa, and its own economic power, this would not be an improbable or unconvincing proposition to see in a post-Western world.

In the final analysis, however, the responsibility lies with African leaders and their governments. There must be common requirements, needs and positions made by African leaders that represent their people and the needs of their countries. The leaders must take a stand and represent a position. This could be done through regional blocs which focus on strategic approaches to development based on what certain regions in Africa need. Regional blocs will enable African countries to 'leverage support from one another to encourage cross country exchange of information' and will increase their bargaining power at international aid and development negotiations (Gilpin, 2020). These would need to be strategically devised, taking into consideration all stakeholders, but especially to ensure that Africa does not succumb to another generation or 'new wave of exploiters' keen to take advantage of the continent's resources (Keet, 2010: 24). Chinese officials are also aware of the criticisms posed against them and are willing to discuss these matters. The issue they find, however, is that African governments do not pose them as policy discussions to be had. Thus, African leaders must take responsibility for this.

Second, China's aid relationship with Africa does challenge the NLWO by changing the norms which underpin international development. The paper sought to demonstrate this through the normative difference that China's aid poses and how it differs from neoliberal economic policies. For this reason, Western donors no longer have the hegemonic power to dictate developmental terms to African countries. By pursuing development-first approaches, China can offer African countries gradual industrial development which, if harnessed correctly, can potentially delink Africa from its peripheral position in the world systems. One reason being is that China's aid essentially contradicts the 'idea of international marginalisation of Africa', bringing favourable economic and political outcomes for the parties involved (Tull, 2006: 459). For this to come to fruition, however, African agency must increase; African leaders should proactively seek ways to capitalise on the opportunities that China has provided for them for their own gain, using these opportunities to increase their own economic leverage and power in the international system. One way this could be done is to study and learn from Chinese economic development, and become well-trained in disciplines such as engineering, with an Afro-centric economic perspective. Similarly, African leaders should employ well-trained contract lawyers to oversee negotiations and agreements with the Chinese to ensure any unfavourable terms are dealt with fairly and robustly to prevent the possibility of any so-called 'debt-trap diplomacy'. Because, despite terms such as 'win-win' and a language of partnership, a truth that must be faced, and recognised, is that there exists an asymmetrical relationship between China and Africa. It is not necessarily one that is similar to the 'North'-'South' relationship in terms of power, but one that simply reflects the uneven economic development and human capital capabilities of both the continent and China. Such factors must be consciously faced, and policies implemented, to hedge against China making far greater gains from the Sino-African relationship.

It must, therefore, be asked: what will happen to Africa once China is able to reach the status of a major power in the international system? One option is that as China grows and becomes more powerful, its current norms and principles may no longer underpin its operations in Africa. Concepts such as 'win-win' and 'equality' may become less important as China begins to adopt more realpolitik policies. African leaders should be wary of this possibility and ensure that they 
do not switch dependency from the West to the East as this could potentially lead to a repeat of the current NLWO, but with China as the leader. Needless to say, the NLWO is witnessing a gradual change in international power dynamics. By critically studying how the IAS and NLWO maintain and support each other, we can see how China's relationship with Africa is challenging the status quo, gradually tilting the pendulum of power from the West to the East. Further into the future, the international system may also begin to appear more multipolar as other countries, such as India and Brazil, begin to play an increasingly more prominent role in international affairs. African countries should begin to recognise this and start to formulate strategies and policies that will enable them to accrue benefits from these various competitors in international trade and economic development. In doing so, they should ensure that their policies never allow let them return to the position of dependency that the NLWO forced upon them. It is this necessity to 'delink' from the global capitalist economy that should underpin all of Africa's interactions with China, ensuring that the continent leaves the Sino-African aid relationship better than how it began.

\section{Funding}

The author(s) received no financial support for the research, authorship and/or publication of this article.

\section{ORCID iD}

Shaquille Ifedayo Gilpin (D) https://orcid.org/0000-0002-3129-297X

\section{Notes}

1. For the purposes of this paper, aid is defined 'as the sum total of both concessional loans and grants' sent to African countries (Moyo, 2010: 9). This does not include emergency or charity-based aid, as it is the billions of dollars sent from the rich to the poor that has had the biggest impact on African development.

2. See Samir Amin's (1987) A Note on the Concept of Delinking. Delinking can be understood as a way to cut oneself off from something. In international relations, it is 'a kind of active anti-globalization which is in dialectical relationship with globalization itself' (Hannerz, 1996: 18). That is, it is about subordinating global economic relations to domestic development.

3. There is a long historical record of aid which is often omitted from Western literature. This includes historical exchanges between leaders in precolonial Africa to imperial China's tributary system. See Markovits et al. (2019) for further research.

4. See Figure 1 in Appendix 1.

5. In part, this is because foreign aid gives many African leaders the funds they need to provide domestic services to their citizens (since they lack the economic infrastructure to generate the funds themselves), which increases their political legitimacy. If this aid is removed, it is possible that this political legitimacy will also be threatened. It is this circular relationship between aid (which increases political legitimacy) and a fear of losing domestic support that provides strong incentives for African governments to remain in the position of dependency.

6. There are some nations which make up the semi-periphery, those which are neither core nor periphery nations like the BRICS (Brazil, Russia, India, China and South Africa).

7. For a theoretical model on the relationship between aid and debt in developing countries, see Cahill and Isely (2000).

8. It must be noted, however, that this is also caveated by compelling evidence of the negative impacts neoliberal economic policies had on Uganda.

9. China critics tend to cite the case of Sri Lanka in 2017 as an example of debt-trap diplomacy. They argue that China offered loans to Sri Lanka to build facilities at Hambantota Port and when Sri Lanka could no longer repay the loans, China sought to take over the port for 99 years. However, as Brautigam (2019) highlights, 'the evidence for this project being a part of a Chinese master plan is thin'. 
10. 'CARI employs a rigorous methodology that results in high quality data collections. For a detailed discussion of their methodology, see their research guidebook (Brautigam and Hwang, 2017)'. (Singh, 2020: 251).

11. See Figure 2 in Appendix 1.

12. Future research should be conducted on the varying degrees of development between South countries and how this may impact South-South cooperation and development in the future.

\section{References}

Adamu PA (2013) The Impact of Foreign Aid on Economic Growth in ECOWAS Countries: A SimultaneousEquation Model. Helsinki: UNU-WIDER.

Addis A, Asongu S, Zuping Z, et al. (2020) Chinese and Indian investment in Ethiopia: infrastructure for 'debt-trap diplomacy' exchange and the land grabbing approach. International Journal of Emerging Markets 16(6): 998-1025.

Agbebi M and Virtanen P (2017) Dependency theory - a conceptual lens to understand China's presence in Africa? Forum for Development Studies 44(3): 429-451.

Alghamdi MA (2016) Does foreign aid promote growth? Evidence from Africa. MSc Thesis, Eastern Illinois University, 2513.

Amin S (1977) Imperialism and Unequal Development. Hassocks: Harvester. Print. Marxist Theory and Contemporary Capitalism.

Amin S (1987) A note on the concept of delinking. Review (Fernand Braudel Center) 10(3): 435-444.

Benjelloun W (2015) China-Africa Co-Operation: Capacity Building and Social Responsibility of Investments. Johannesburg, South Africa: South African Institute of International Affairs.

Biryabarema E (2017) IMF's Lagarde says Uganda needs to rely less on credit for infrastructure. Reuters. Available at: https://www.reuters.com/article/us-uganda-imf-idUSKBN15B1V3 (accessed 18 August 2021).

Brautigam D (2011) The Dragon's Gift. Oxford: Oxford University Press.

Brautigam D (2019) Misdiagnosing the Chinese Infrastructure Push. The American Interest. Available at: https:/www.the-american-interest.com/2019/04/04/misdiagnosing-the-chinese-infrastructure-push/ (accessed 1 November 2021).

Brautigam D and Hwang J (2016) Eastern promises: New data on Chinese loans in Africa, 2000 to 2014. Working Paper 4. China-Africa Research Initiative, School of Advanced International Studies, John Hopkins University. Available at: https://static1.squarespace.com/static/5652847de4b033f56d2bdc 29/t/58ac91ede6f2e1f64a20d11a/1487704559189/eastern+promises+v4.pdf (accessed 25 August 2021).

Brautigam D and Hwang J (2017) China-Africa Loan Database Research Guidebook. China-Africa Research Initiative, School of Advanced International Studies, John Hopkins University. Available at: https:// static1.squarespace.com/static/5652847de4b033f56d2bdc29/t/58ac6353f7e0ab024bcc665c/1487 692628411/guidebook + draft + v.26.pdf (accessed on 25 August 2021).

Cahill MB and Isely PN (2000) The relationship between aid and debt in developing countries. The American Economist 44(2): 78-91.

Chen Y, Sun IY, Ukaejiofo RU, et al. (2016) Learning from China? Manufacturing, investment, and technology transfer in Nigeria. Working Paper 2, January. China-Africa Research Initiative, School of Advanced International Studies, John Hopkins University.

China-Africa Research Initiative (CARI) (2020) Risky Business: New Data on Chinese Loans and Africa's Debt Problem School of Advanced International Studies, John Hopkins University.

China International Development Cooperation Agency (CIDCA) (2011) China's Foreign Aid (2011). Available at: http://en.cidca.gov.cn/2018-08/09/c_261159.htm (accessed 28 August 2021).

Dams T and van der Putten F (2015) China and liberal values in international relations opposing the promotion of democracy, human rights and liberal market economy. Clingendael Report, Clingendael Netherlands Institute of International Relations, Den Haag.

Easterly W (2002) The cartel of good intentions: the problem of bureaucracy in foreign aid. Journal of Policy Reform 5(4): 223-250. 
Financial Times (2016) Hillary Clinton: The China hawk. Available at: https://www.ft.com/content/92b23c8e7349-11e6-bf48-b372cdb1043a (accessed 10 September 2021).

Fuchs A and Rudyak M (2019) The motives of China's foreign aid. In: Zeng K (ed.) Handbook of the International Political Economy of China. Cheltenham: Edward Elgar Publishing, 391-410.

Gallagher KP (2016) The China Triangle: Latin America's China Boom and the Fate of the Washington Consensus. New York: Oxford University Press.

Gilpin S (2020) Poor institutions or unfair power dynamics? Notes from Sierra Leone's Alluvial Diamond Industry. The Republic. Available at: https://republic.com.ng/june-july-2020/sierra-leone-diamondindustry/ (accessed 12 September 2021).

Gunder F (1986) The development of underdevelopment. In: Klaren PF and Bossert TJ (eds) Promise of Development: Theories of Change in Latin America. United States: Westview Press, 111-123.

Hannerz U (1996) Transnational Connections: Culture, People, Places. London: Routledge.

Harrison G (2019) Authoritarian neoliberalism and capitalist transformation in Africa: all pain, no gain. Globalizations 16(3): 274-288.

Hussein K, Christophe P and Hitimana L (2005) Economic and Social Importance of Cotton in West Africa: Role of Cotton in Regional Development, Trade and Livelihoods. Paris: Sahel and West Africa Club Secretariat/OECD.

Ikenberry G (2018) Why the liberal world order will survive. Ethics \& International Affairs 32(1): 17-29.

Jubilee Debt Campaign (2018) Africa's Growing Debt Crisis: Who Is the Debt owed To? London: Jubilee Debt Campaign. Available at: https://jubileedebt.org.uk/wp/wp-content/uploads/2018/10/Who-isAfrica-debt-owed-to_10.18.pdf. (accessed 21 August 2021).

Kabonga I (2017) Dependency theory and donor aid: a critical analysis. Africanus: Journal of Development Studies 46(2): 29-39.

Keet D (2010) South-South strategic bases for Africa to engage China. In: Cheru F and Obi C (ed.) The Rise of China and India in Africa: Challenges, Opportunities and Critical Interventions. London: Zed Books, 21-33.

Lagarde C (2017) Becoming the Champion: Uganda's Development Challenge. International Monetary Fund. Available at: https://www.imf.org/en/News/Articles/2017/01/27/sp01272016-Becoming-the-Champion-Ugandas-Development-Challenge (accessed 2 September 2021).

Lin JY (2016) How to jumpstart industrialisation and economic transformation in Africa in China-Africa: a maturing relationship? In: Calabrese L (ed.) China-Africa: A Maturing Relationship? Growth, Change and Resilience, DEGRP Policy Essays, 8-12.

Mahembe E and Odhiambo NM (2021) Does foreign aid reduce poverty? A dynamic panel data analysis for sub-Saharan African countries. Journal of Economic Inequality 19: 875-893.

Markovits D, Strange A and Tingley D (2019) Foreign aid and the status quo: Evidence from Pre-Marshall Plan Aid. The Chinese Journal of International Politics 12(4): 585-613.

Maswana J (Jan 4-7 2007) China-Africa's Emerging Economic Links: A Review Under the Core-Periphery Perspective. Munich: University Library of Munich.

Maswana J-C (2018) Revisiting the growth effects of Sino-African Bilateral Trade on African Economies. In: American Economic Association 2018 AEA/ASSA Conference, Philadelphia, PA, 4-7 January.

Ministry of Foreign Affairs of the People's Republic of China (2015) Xi Jinping attends high-level dialogue of China-Africa leaders and business representatives and closing ceremony of the 5th China-Africa Business Forum and delivers an important speech, stressing to embrace proud tradition of China-Africa Sincere Friendship and Catapult African Industrialization Renaissance. Available at: https://www. fmprc.gov.cn/mfa_eng/topics_665678/2015zt/xjpffgcxqhbhbldhdjbbwnfjxgsfwbfnfyhnsbzczfhzltfh/ t1322277.shtml (accessed 8 September 2021).

Molina N and Pereira J (2008) Critical Conditions: The IMF Maintains Its Grip on Low-Income Governments. Brussels: EURODAD.

Moyo D (2010) Dead Aid. London: Penguin Group.

Naim M (2009) Rogue aid. Foreign Policy. Available at: https://foreignpolicy.com/2009/10/15/rogue-aid/ (accessed 8 September 2021). 
Ocampo J (2001) International Asymmetries and the Design of the International Financial System. Santiago: Naciones Unidas, CEPAL. Available at: https://repositorio.cepal.org/bitstream/handle/11362/7776/1/ S01040327_en.pdf. (accessed 3 September 2021).

Ohno I and Niiya Y (2004) Good Donorship and the Choice of Aid Modalities - Matching Aid with Country Needs and Ownership -. Tokyo: GRIPS Development Forum.

Omotola J and Saliu H (2009) Foreign aid, debt relief and Africa's development: problems and prospects. South African Journal of International Affairs 16(1): 87-102.

Opoku-Mensah P (2010) China and the international aid system: transformation or cooptation. In: Xing L (ed.) The Rise of China and the Capitalist World Order. United Kingdom: Ashgate Publishing, 71-87.

Oxfam International (2006) Kicking the habit. Oxfam Briefing Paper, Oxfam, Nairobi, Kenya.

Oya C and Wanda F (2019) Condições de emprego em Angola. Construção de obras públicas e indústria de materiais de construção. IDCEA Research Report. SOAS, University of London, London.

Pan Y (2015) China's foreign assistance and its implications for the international aid architecture. China Quarterly of International Strategic Studies 1(2): 283-304.

Pérez F (2021) East Asia has delinked - can Ethiopia delink too? Review of African Political Economy 48(167): 102-118.

Perkins J (2017) The New Confessions of an Economic Hitman: How America Really Took Over the World. London: Ebury Press.

Perlez J (2006) China competes with West in aid to its neighbors. Available at: https://www.nytimes. com/2006/09/18/world/asia/18china.html. (accessed 26 August 2021).

Phillips M (2006) G-7 to warn China over costly loans to poor countries. WSJ. Available at: https://www.wsj. com/articles/SB115826807563263495 (accessed 8 September 2021).

Quirk P, Flockhart T, Kupchan C, et al. (2014) Liberal Order in a Post-Western World. Washington, DC: Transatlantic Academy.

Rafferty T (2011) China in Africa: implications for the international development regime. St Antony's International Review 6(2): 27-46.

Reuters (2015) Mali signs \$1.5 bln rail deal with China Railway Construction. Available at: $<$ https://www. reuters.com/article/mali-china-cn-railway-const-idUSL8N14F06320151226> (accessed 13 September 2021).

Schaefer F and Oya C (2019) Chinese Firms and Employment Dynamics in Africa: A Comparative Analysis. Synthesis Report. IDCEA Research Brief - Ethiopia. London: SOAS, University of London.

Sempiga O (2017) Does China offer a new narrative and an alternative voice in International Relations? Journal of International Relations, Peace Studies, and Development 3(1): 1-15.

Sikamo J, Mwanza A and Mweemba C (2016) Copper mining in Zambia - history and future. Journal of the Southern African Institute of Mining and Metallurgy 116(6): 491-496.

Singh A (2020) The myth of 'debt-trap diplomacy' and realities of Chinese development finance. Third World Quarterly 42(2): 239-253.

Situmbeko L and Zulu JJ (2004) Zambia: Condemned to Debt: How the IMF and World Bank Have Undermined Development. London: World Development Movement.

Stern E (2008) The Paris Declaration, Aid Effectiveness and Development Effectiveness. Copenhagen: Ministry of Foreign Affairs.

Sun S, Xu X and Zhao X (2021) China's foreign aid training: targeting becoming an influential culture sharer. Journal of Asian and African Studies 56(4): 851-871.

Tarrósy I (2020) China's Belt and Road Initiative in Africa, debt risk and new dependency: the case of Ethiopia. African Studies Quarterly 19(3-4): 8-28.

Taylor I and Zajontz T (2020) In a fix: Africa's place in the Belt and Road Initiative and the reproduction of dependency. South African Journal of International Affairs 27(3): 277-295.

Truman H (1949) Truman's Four Points Speech| Wyzant Resources. Available at: https:/www.wyzant.com/ resources/lessons/history/hpol/truman/four-points. (accessed 22 August 2021).

Tull DM (2006) China's engagement in Africa: scope, significance and consequences. The Journal of Modern African Studies 44(3): 459-479. 
UN (2020) South-South Cooperation Day | United Nations. Available at: https://www.un.org/en/observances/ south-south-cooperation-day (accessed 12 September 2021).

USAID (2021) USAID 101. Available at: https://www.usaid.gov/fallsemester/usaid-101 (accessed 13 September 2021).

Vadell J, Ramos L and Neves P (2014) The international implications of the Chinese model of development in the Global South: Asian Consensus as a network power. Revista Brasileira de Politica Internacional 57: 91-107.

Voice of America (2018) Pompeo: China Engaging in 'Predatory Economics 101'. Available at: https:// www.voanews.com/usa/pompeo-china-engaging-predatory-economics-101 (accessed 12 September 2021).

Wade A (2008) Time for the west to practise what it preaches. Financial Times. Available at: https://www. ft.com/content/5d347f88-c897-11dc-94a6-0000779fd2ac (accessed 26 August 2021).

Wallerstein I (1974) The rise and future demise of the world capitalist system: concepts for comparative analysis. Comparative Studies in Society and History 16(4): 387-415.

Whitfield L (2009) Reframing the aid debate: why aid isn't working and why it should be changed. DIIS Working Paper 34. Copenhagen: Danish Institute for International Studies.

Wiegratz J, Martiniello G and Greco E (2018) Uganda: The Dynamics of Neoliberal Transformation (Politics and Development in Contemporary Africa). London: Zed Books.

Williams D (2013) The history of international development aid. In: Moschella M and Weaver C (eds) Handbook of Global Economic Governance. Abingdon: Routledge, 233-248.

Woods N (2008) Whose aid? Whose influence? China, emerging donors and the silent revolution in development assistance. International Affairs 84(6): 1205-1221.

World Bank (2005) International Development Association Program. Document for a Proposed Fourth Structural Adjustment Credit. Washington, DC: World Bank.

Xin Z (2018) China Focus: China pursues world peace, common development in international agenda-Xinhua| English.news.cn. Xinhua. Available at: http://www.xinhuanet.com/english/2018-03/02/c_137011860. htm (accessed 11 September 2021).

Xinhua (2018) Full text of Chinese President Xi Jinping's speech at opening ceremony of 2018 FOCAC Beijing Summit - Xinhua| English.news.cn. Available at: http://www.xinhuanet.com/english/201809/03/c_129946189.htm (accessed 30 August 2021).

Xinhua (2021a) No evidence of China's engagement in 'debt-trap diplomacy': media - Xinhua| English. news.cn. Available at: http://www.xinhuanet.com/english/asiapacific/2021-02/24/c_139764009.htm (accessed 5 September 2021).

Xinhua (2021b) Zambian leader commissions Chinese-built power plant - Xinhua| English.news.cn. Available at: http://www.xinhuanet.com/english/africa/2021-07/24/c_1310081465.htm (accessed 7 September 2021).

Zan S (2015) Economic impact of China's investments in Mali's construction sector on Mali. Journal of International Relations and Foreign Policy 3(2): 27-33.

Zhang Y (2013) On Samir Amin's Strategy of 'Delinking' and 'Socialist Transition'. International Journal of Business and Social Research 3(11): 101-107.

\section{Author biography}

Shaquille Ifedayo Gilpin is a Peking University-LSE Double MSc student in International Affairs, currently in his second year of study at the London School of Economics. Prior to starting his masters, he graduated from the University of Warwick in Politics and International Studies. He is particularly interested in China-Africa relations, and the international political economy, and hopes to work at the cross-section of UK-China-Africa relations as a diplomat. 


\section{Appendix I}

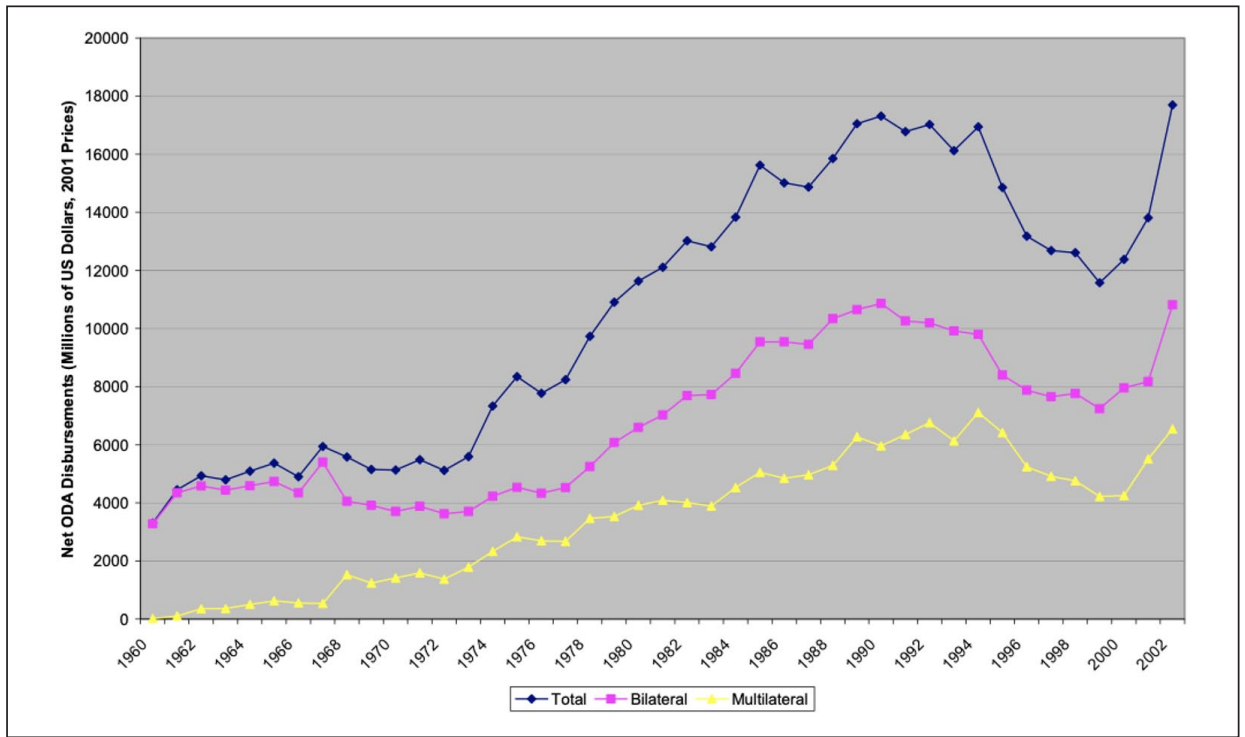

Figure I. Aid flows to sub-Saharan Africa, 1960-2002.

Source: McGillray (2003) Is aid effective? Discussion Paper No. 2003/7I. Helsinki: World Institute for Development Economics Research, United Nations University.

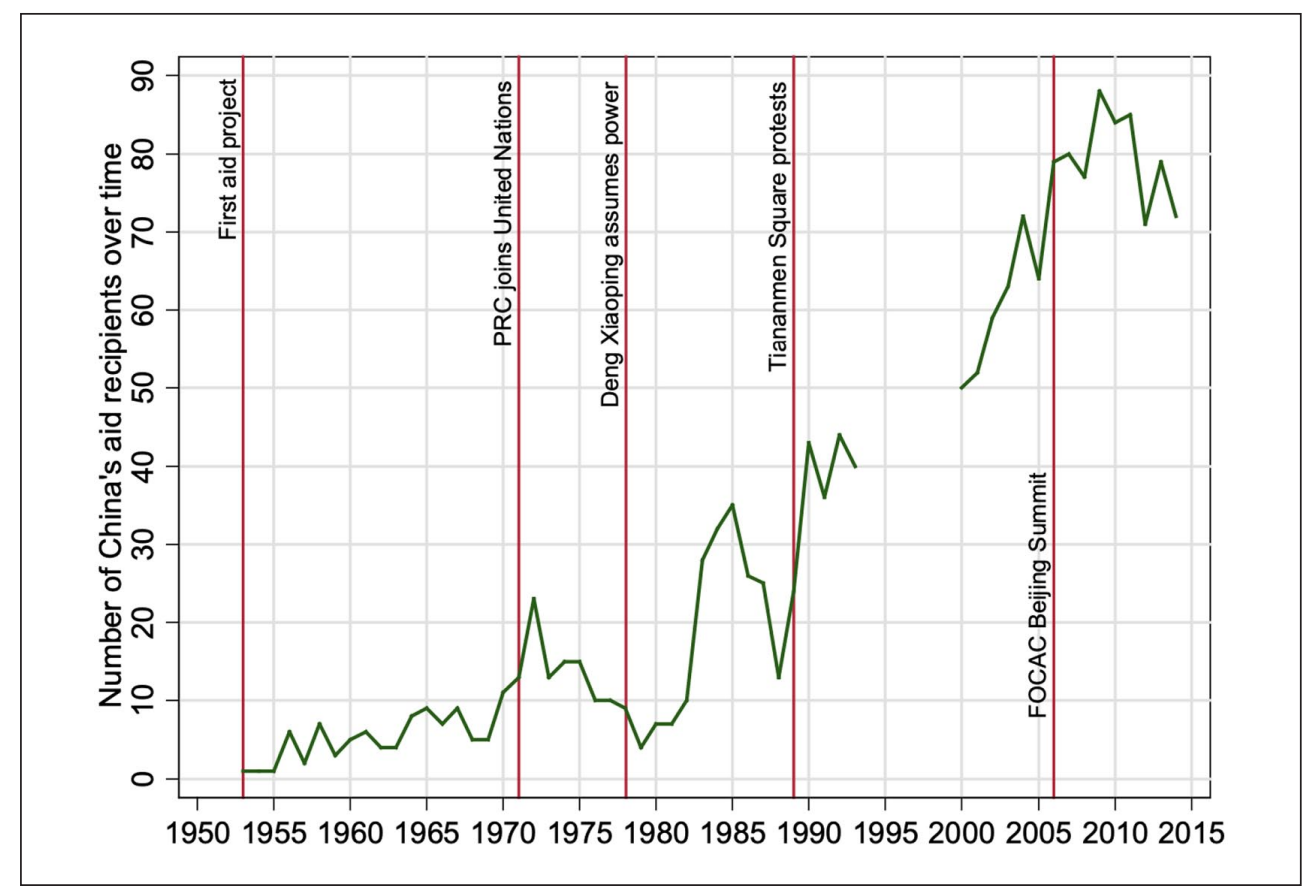

Figure 2. Number of Chinese aid recipients over time (1953-2014).

Source: Fuchs and Rudyak (2019). 